\title{
PROGRAM TALK SHOW DAN RUANG PUBLIC SPHERE: UPAYA MEDIA SEBAGAI INDUSTRI PRO PUBLIK
}

\author{
Juniawati
}

\begin{abstract}
Abstrak
Berlimpahnya informasi menjadikan industri penyiaran mempunyai nilai jual yang tinggi, inilah yang menjadi alasan pula sehingga ramai bermunculan media elektronik di Indonesia. media massa khususnya media elektronik seperti televisi mampu memesona imajinasi publik. Media ini juga mampu membangun struktur ekspektasi jiwa secara bertahap layaknya sekolah. Masih minimnya ketersediaan media massa memberikan ruang bicara dan partisipasi masyarakat menjadi peluru bagi media massa untuk berperan lebih aktif menjemput ekspresi khalayak atau massa yang jumlahnya tidak terbatas ruang dan waktu ini untuk kemudian memberikan poin-poin positif bagi pemerintah, media maupun maasyarakat lewat program perbincangan atau talk show
\end{abstract}

Kata Kunci: Media, Informasi, Tantangan Ideologi

\section{A. Pendahuluan}

Sumber daya manusia sebagai modal dasar maju dan berkembangnya suatu bangsa dan negara perlu adanya peningkatan dan penempaan, terutama yang terkait dengan kesadaran masyarakat akan pentingnya pendidikan, kesehatan dan sosial budaya. Hal ini dilakukan mengingat semakin terbukanya wawasan dan cakrawala dunia dalam era globalisasi khususnya dalam bidang informasi.

$$
\text { Pengelolaan media dan }
$$

transformasi informasi menjadi penting manakala menjadi konsumsi masyarakat hingga hari ini. Hal ini berimplikasi pada serapan informasi yang menyangkut hajat hidup orang banyak diterima.

Melvin De Fluer menyebutkan bahwa media massa merupakan sumber utama informasi mengenai kejadian seluruh dunia. Sehingga kehadirannya ditunggu oleh masyarakat. Melalui media masyarakat menjadi kebiasaan mendengar acara tertentu di radio atau menonton televisi adalah salah satu pemandangan yang umum di masyarakat. Alhasil, tidak jarang muncul sikap kebergantungan masyarakat terhadap 
program atau sajian dari media. Sehingga di radio atau televisi sering kita dengar ada pendengar atau penonton panatik. Ini menunjukkan sedemikian tinggi kesan atau pengaruh media yang diberikan hingga kepada perilaku khalayak menjadi demikian besar.

Ragam kemasan informasi dan hiburan di media yang ada, tidak lepas dari pengaruh beralihnya sistem negara ini dari rezim orde baru dan mengantarkannya kepada sistem demokrasi yang memberikan kebebasan berekspresi. Hal ini disambut positif oleh insan penyiaran dengan semakin bersemangat terlibat di dunia penyiaran. Dengan berlimpahnya informasi menjadikan industri penyiaran mempunyai nilai jual yang tinggi, inilah yang menjadi alasan pula sehingga ramai bermunculan media elektronik di Indonesia.

Adapun program bicang-bincang atau talk show yang hari ini telah meramaikan media elektronik seperti Metro TV dengan acaranya mata najwa di Metro TV yang berhasil meraih beberapa penghargaan bergengsi seperti KPI Award 2014 sebagai talkshow terbaik. Ada pula Aiman dan Jusuf Kalla atau interupsi (sumber www.kpi.go.id, 2014) atau Kick Andy di Metro TV yang sarat dengan pesan humanity dan Sarah sehchan di Net TV yang menjadi presenter talkshow terbaik KPI Award 2014. Booming talk show di negara adidaya Amerika juga tak kalah menarik dan dikenal masyarakat. Oprah Winfrey menjadi acara talk show berpengaruh sepanjang sejarah industri informasi di negara ini.

Fenomenal penggunaan informasi di media kemudian menimbulkan kepuasan yang pantas bagi masyarakat terekam melalui kebutuhan masyarakat yang lebih individual secara pribadi. Orientasi media seseorang sedemikian ini seperti disebutkan Mc Leod dan Mc Donald, 1990 (McQuail,2011) sebagai hasil gabungan dari latar belakang sosial dan pengalaman media masa lalu dan mengambil bentuk hubungan dari media tertentu, kesukaan dan kepentingan spesifik, kebiasaan penggunaan.

Menariknya fenomena kemasan informasi berita, yang kini semakin menjadi primadona di masyarakat. Menunjukkan bahwa informasi tidak lagi sekedar pelengkap program acara di media televisi maupun radio, tapi menjadi amunisi media yang utama dan memegang peranan penting hingga suatu media bisa dikenal atau tidaknya.

\section{B. Media Massa Dan Public Sphere}

Media sebagai institusi sosial masyarakat menjadi sarana efektif dalam 
menyampaikan informasi secara massif. Dengan berbagai model penyampaian pesannya, media mampu memberikan ruh positif pada kehidupan masyarakat. Ibnu Ndzir peneliti dari LIPI Indonesia menyebutkan bahwa media sosial pada tahun 2013 mencapai 75,57 juta (Muhammad

Yudhi, www.ahlulbaitiindonesia.org/berita).

Media massa yang dipercaya mampu membangun demokrasi Indonesia menjadi lebih baik dan beradab setidaknya bukan hanya isapan jempol. Sebagai ruang publik yang disediakan masyarakat Indonesia, media massa tidak sekadar berdiri dan beroperasi. Media massa sebagaimana fungsinya menjadi penyeimbang berbagai kepentingan dan membawa nilai-nilai konstruktif bagi masyarakat.

Desakan yang amat kuat akan hadirnya media massa dimotori beberapa alasan yang tidak hanya menjadikan media sebagai artefak budaya. Media masa menjadi sumber memperoleh citra realitas sosial serta interpretasinya. Penilaian publik atas suatu peristiwa adalah berawal dari penilaian media. Kedua, media massa sedikit banyak menjadi pengembangan budaya dalam arti luas. Meresap pada tatacara, mode, gaya hidup dan norma-norma. Budaya massa adalah hasil dari produksi media. Ketiga media mempunyai aturan sendiri yang mengsinergikan dirinya dengan institusi lain dalam masyarakat. Keempat, media massa adalah media kontrol, manajemen dan inovasi yang aktif dan dinamis dalam masyarakat. Kelima, media massa tiada lain adalah forum ekspresi dan aspirasi masyarakat. Keenam, Sebagai organisasi yang kompleks media bisa dipelajari, profesional, kompleks kerja dan budaya. Ketujuh, media mengandung industri barang dan jasa yang makin dibidik masyarakat di daerah sebab sebagai lahan baru dalam membangun ekonomi daerah (Nunung Prajarto, 2004).

Pengaruh kehadiran media massa khususnya media elektronik seperti televisi mampu memesona imajinasi publik. Media ini juga mampu membangun struktur ekspektasi jiwa secara bertahap layaknya sekolah. Media elektronik dikatakan George Comstock dalam bukunya Television in America televisi telah menjadi faktor tak tererlakkan dan tak terpisahkan dalam membentuk diri kita dan akan seperti diri kita nanti (John Vivian, 2008)

Begitu pula dengan media elektronik radio. Pengaruhnya demikian besar ketika di Amerika serikat acara talk show di radio menjadi hangat di telinga warga amerika. Lebih dari 660 stasiun radio dan 20 juta orang yang mendengarkan acara tersebut tiap 
minggu dan $44 \%$ masyarakat di negara ini mendapat informasi politik kebanyakan dari acara bincang-bincang di radio (John Vivian, 2008).

Di Indonesia, semangat industri media tak mau ketinggalan. Media elektronik kian hari mendapat kepercayaan masyarakat, sehingga makin marak bermunculan. Sejarah media penyiaran di Indonesia telah melalui perjuangan yang tidak singkat. Setidaknya terekam dalam sejarah sistem penyiaran di Indonesia. Sebelum reformasi media elektronik mengalami jalan di tempat, tertekan dan menjadi bagian dari alat politik penguasa orde baru (Juniawati, 2013). Sejalan dengan perkembangan industri media massa hari ini pasca "revolusi Mei 1998" reformasi media penyiaran membuka peluang dan kesempatan yang sama untuk bebas menyampaikan ide dan pendapat.

Komisi Penyiaran Indonesia (KPI) menyebutkan pertumbuhan televisi mulai bergairah ketika tahun 1990-an, ketika TVRI tidak lagi menjadi pusat media untuk televisi. Pertumbuhan televisi di Indonesia mencapai puncaknya pada tahun 2001-2002 dengan hadirnya 5 televisi swasta baru, yaitu:

1. Trans TV

2. TV 7 yang pada periode berikutnya menjadi Trans 7
3. Lativi yang diakuisisi Bakrie grup dan berubah menjadi TV One

4. Global TV dan

5. Bali TV

Perkembangan industri televisi didahului oleh hadirnya 6 telivisi swasta yaitu:

1. RCTI

2. SCTV

3. TPI beberapa tahun kemudian menjadi MNC TV

4. Antv

5. Indosiar

6. Metro TV

Fenomena penyiaran televisi terus menampakkan diri sebagai industri yang berkembang pesat ditandai dengan kehadiran beberapa televisi seperti di tahun 2003 TVB, tahun 2005 Spacetoon dan 2007 SINDO TV hingga pada tahun 2011 Kompas TV dan B Channel mewarnai pertelevisian Indonesia (Wahyu Wibowo, 2013).

Berdasarkan kondisi media hari ini, penetrasi media massa di Indonesia yang mencapai $95 \%$ dari total penduduk Indonesia yang 240 juta jiwa. Tercermin melalui media radio yang telah mencapai $47 \%$, koran $25 \%$, majalah $13 \%$, telpon seluler 270 juta dan internet $29 \%$ (www. Kominfo.go.id).

Melihat kenyataan di atas, menunjukkan media berpeluang besar sebagai ruang diskusi dan penyampaian 
pendapat dan model partisipasi massa. Hal ini menarik untuk dicermati, mengingat media massa dengan bermacam kecenderungan juga mempunyai banyak pertimbangan ekonomi. Sejatinya, media massa sebagai fasilitas sosial yang ada menggiring kesan bahwa manusia mampu merefleksikan dirinya secara kritis, baik secara politis-ekonomis maupun budaya. Dimana struktur masyarakat umumnya mempunyai kebabasan dari dominasi dan emasifatif. Setiap individu secara substansi memiliki kesempatan yang sama untuk berpartisipasi dalam berbagai kesempatan, termasuk di media.

Model partisipasi ini dalam konsep public sphere yang disebut Hubermas merupakan wilayah sosial yang bebas dari dominasi yang memungkinkan kehidupan sosial kita untuk membentuk opini publik yang relatif bebas. Konsep ini berangkat dari realitas sosial yang ada dalam masyarakat, dimana proses pertukaran informasi dari berbagai pandangan mengenai suatu permasalahan publik (trend setter) di masyarakat yang kemudian menjadi opini umum.

Dalam praktik pertukaran pandangan yang terbuka dan diskusi mengenai masalah-masalah kepentingan sosial umum. Penekanan dari konsep ini adalah pada pembentukan kepekaan (sense of public) dimana sebagai praktik sosial yang melekat secara budaya. Alhasil, hadirnya public sphere sebagai ruang publik yang kuat, yang bersifat inklusif, objek yang didiskusikan dapat diakses siapa saja.

Media dan public sphere menurut Hubermas menjadi bagian integral. Meski sedikit muncul keraguan terhadap media dalam menjaga perannya menjalankan fungsi sosial. Konsep public sphere ini mengantarkan kita kepada akan pentingnya sistem komunikasi publik yang dibangun oleh media. Ketika menoleh kebelakang media massa di jaman orde baru dengan sistem politik media sebagai alat negara mengembangkan idiologi (ideological state apparatus) (Nunung Prajarto, 2004). Maka dalam sistem keleluasaan informasi pasca reformasi, posisi media telah keluar dari stigma negatifnya sebagai corong pemerintah. Dalam kesempatan yang sama muncul beberapa dukungan untuk media bisa tumbuh dan berkembang mengawal demokrasi di Indonesia. Sebagaimana yang disebut Nunung Prajarto (2004) yang terlembaga secara jelas melalui:

1. Undang-undang RI No. 36 Th. 1999 tentang Telekomunikasi

2. Undang-undang No. 40/1999 tentang kebebasan Pers 
3. Peraturan Pemerintah No. 36 tahun 2000 tenang Pendirian Perusahaan Jawatan TVRI-RRI

Lebih lanjut, menurut Agus Sudibyo (2004) idealnya ruang publik (public sphere) yang merupakan hasil ramuan jurnalistik profesionalnya media massa adalah dengan memberikan porsi yang setara kepada semua pihak, tanpa membeda-bedakan siapa yang berpendapat dan klaim-klaim yang muncul terhadap suatu persoalan.Lahirnya opini masyarakat di media tentunya memiliki kekuatan yang besar hasil dari konstribusi pandangan individiu yang beragam tadi. Karena itu, mengingat pentingnya ide yang tertuang dalam ruang publik dan relevansinya dengan efek media maka media diharapkan memiliki potensi yang cukup untuk mempengaruhi opini individu walaupun sebagian besar tidak disengaja dengan mmenyediakan informasi atau isu yang ada dan memberikan pilihan atas isu tersebut (McQuail,2011).

Sebab bagaimanapun juga media massa memiliki kekuatan konstruktif dalam hal menarik perhatian khalayak lewat stimulus yang diberikan secara langsung ke individu yang berhubungan dengan sikap sosial, pilihan politik idiologi dan opini publik. McQuail (2011) melihat perubahan induksi media bahwa perubahan manapun dapat terjadi pada level individu, masyarakat, institusi atau budaya:

1. Menyebabkan perubahan yang disengaja

2. Menyebabkan perubahan yang tidak disengaja

3. Menyebabkan perubahan kecil (dalam hal bentuk atau intensitas)

4. Memfasilitasi perubahan (disengaja atau tidak)

5. Memperkuat yang sudah ada (tidak ada perubahan)

6. Mencegah perubahan

Akhirnya, konsep public sphere di media akan mempunyai harapan besar dimana media massa dapat senantiasa menjadi penengah antara kekuatan negara dan publik. Sebab dengan posisi media massa dapat mengakomodir informasi dan menyebarluaskannya demi untuk pembentukan opini publik dan media menyajikan beragam pendapat publik secara emansipatoris dan mencerahkan (Gun Gun Haryanto, 2006).

\section{Talk Show Dalam Media Elektronik}

Program perbincangan atau talk show merupakan kombinasi seni berbicara dan seni wawancara yang dikemas secara santai dan mengangkat tema-tema yang menjadi fenoma terkini di masyarakat. 
Talkshow menjadi bagian dari keterampilan pemandu acara dalam mewawancarai nara sumber terhadap suatu permasalahan aktual/ sedang menjadi sorotan, interaktif dengan nara sumber dengan seimbang dan menghasilkan kesimpulan terbuka (Harley Prayudha, 2004). Perbincangan (talk show) Berdasarkan Keputusan Komisi Penyiaran Indonesia Nomor 009/SK/KPI/8/2004 Tentang Pedoman Perilaku Penyiaran dan Standar Program Siaran Komisi Penyiaran Indonesia pada Pasal 8 disebutkan bila program talk show termasuk di dalam program faktual. Adapun pengertian program faktual merujuk pada program siaran yang menyajikan fakta non-fiksi (Sumber: P3SPS).

Bentuk informasi yang diketengahkan program ini adalah bernilai jurnalistik yang mengangkat fenomena atau isu yang sedang berkembang dan hangat di masyarakat. Kemudian dikemas dengan percakapan sederhana (casual conversation) dengan bahasa yang universal dalam upaya untuk menghadapi heterogenitas khalayak.

Lebih lengkapnya, acara perbincangan diarahkan oleh seorang host yang punya dua kelebihan sekaligus yakni piawai dalam memandu acara sekaligus handal dalam mewawancara. Dalam penyelenggaraan talk show di radio (Morissan, 2008) beberapa bentuknya dapat dilihat secara praktis melalui:

1. One-on-on-show, dimana saat host atau presenter acara dan narasumber mendiskusikan suatu topik dengan dua posisi mikrofon terpisah di ruang studio yang sam.

2. Panel Discussion, pewawancara sebagai moderator hadir bersama sejumlah narasumber

3. Call in show. Perbincangan yang hanya melibatkan telepon pendengar. Dengan didahului penentuan topik oleh host di studio dan juga memberikan contoh pengalaman host untuk kemudian memberikan kesempatan atau partisipasi dari pendengar.

Format siaran talk show sendiri tidak terlepas dari peran stasiun penyiaran yang menyelenggarakan program ini. Menurut Morissan (2008) keberhasilan media televisi maupun radio dalam melaksanakan programnya bergantung pada:

1. The ability to produce or buy prgrams with audience appeal (kemampuan untuk memproduksi atau membeli program yang memiliki daya tarik audien)

2. Air them at times when they can be seen by the audience to which they appeal (menayangkan pada waktu 
yang dapat dilihat audien yang menjadi sasaran)

3. Build individual programs into a schedule that encourages viewers to tune to the station and remain with it from one program to another ( membangun sejumlah program individu ke dalam suatu jadual yang dapat mendorong audien untuk menentukan stasiun dan tetap berada di salurannya dari satu program ke program berikutnya.

\section{Khalayak aktif dan Persoalan kompleks}

Khalayak atau penerima. Khalayak merupakan sekelompok pendengar atau penonton yang memiliki perhatian, reseptif, tetapti relatif pasif yang terkumpul dalam latar yang kurang lebih bersifat publik. Khalayak adalah produk konteks sosial (yang mengarah pada kepentingan budaya, pemahaman, dan kebutuhan informasi yang sama) serta respon kepada pola pasokan media tertentu (McQuail, 2011). Khalayak mempunyai gaya pemikiranya yang tersendiri, yang kompleks dan berbeda berdasarkan beberapa hal. Antara lain menurut Nighthingale (lihat McQuail, 2011). Dalam hal ini khalayak lebih kepada penjelasan karakter yang diberikan media:
1. Khalayak sebagai 'orang-orang yang ditujukan'. Merujuk kepada kelompok orang yang dibayangkan oleh komunikator serta kepada siapa konten dibuat. Ini mengarah kepada siapa yang 'terlibat' atau 'terinterpretasi'

2. Khalayak sebagai 'yang berlangsung'. Pengalaman penerimaan sendirian atau dengan orang lain sebagai peristiwa interaktif dalam kehidupan sehari- hari, berlangsung dalam konteks tempat atau fitur lain

3. Khalayak sebagai 'pendengar atau audisi'. Lebih kepada pengalaman khalayak yang berpartisipasi, manakala khalayak ditempelkan di dalam sebuah pertunjukkan atau diperkenankan untuk ikut terlibat melalui alat yang jauh atau memberikan respon di saat yang bersaman.

Sementara khalayak dari asalnya berada (masyarakat itu sendiri) yang memiliki banyak ciri:

1. Merencanakan dan mengatur kegiatan menonton dan mendengarkan

2. Tindakan pilihan dan perhatian individual yang sukarela

3. Khalayak media massa lebih beragam dalam dalam hal konten yang tersedia dan perilaku sosial yang terlibat

4. Khalayak media massa tertarik pada pasokan konten untuk memenuhi 
kepuasan alih-alih terbentuk dalam respons pertunjukkan dan ketertarikan berkala

\section{Berikut tipologi pembentukan khalayak media massa}

\section{SUMBER}

\section{Masyarakat}

Level Makro: Sekelompok atau publik sosial

Level Mikro: Penagkat Kepuasan

Sumber: McQuail (2011). Teori Komunikasi Massa.

Adapula, khalayak yang memikirkan bagaimana hendak memuaskan keperluan diri mereka. Sehingga kecenderungan citarasa dan kehendak khalayak juga bisa berubah. Tergantung seberapa besar media massa dapat menjawab kebutuhan yang kompleks.

Hal yang cukup urgen dalam memahami khalayak adalah dengan menetapkan beberapa skill atau kemampuan manajerial dan sumber daya pelaksanaan suatu produk, maka pertimbangan lainnya adalah seperti berikut:

1. Menempatkan aspek demografi khalayak sasaran dari program yang akan dihadirkan

2. Mempertimbangkan kondisi sosial budaya masyarakat
3. Aspek psikologi. Secara umum, aspek ini mesti masuk dalam konten materi acara, perilaku atau sikap host atau presenter acara, kepercayaan, perasaan dan persepsi khalayak serta pengaturan kelengkapan semua produksi dengan berbagai Medzra ${ }^{2}$ timbangan teknis lainnya.

Khalayak media
Khalayakaphun saluran etempanteat ciri khas diantaranya:

1. Khalayak merupakan kumpulan konsumen. Baik konsumen nyata maupun konsumen potensial. Hal ini muncul ketika media menjadi industri bisnis yang semakin besar,maka istilah pasarpun muncul yang merupakan definisi dari khalayak (wilayah yang dilayani) oleh media.

2. Anggotanya tidak saling berkaitan dan tidak memiliki identitas diri bersama

3. Khalayak juga merupakan bentukan yang bersifat sementara

4. Batasan yang ditentukan kepada khalayak umumnya berdasarkan kriteria sosial-ekonomi

5. Kepentingan publik adalah sesuatu yang dinomorduakan

6. Hubungan khalayak dengan media adalah saling perhitungan dan bukan berdasarkan moral.

Terkait dengan persoalan yang kompleks dan hubungannya dengan perilaku khalayak atau audien. Sebagian 
besar perilaku audien akan dijelaskan melalui berbagai kebutuhan (needs) dan kepentingan (interests) individu. Sebagai contoh, banyak orang memilih media dan bentuk program yang di dengar dalam radio berdasarkan sejauhmana media dan program yang dipilih memenuhi kehendak khalayak (Saodah Wok et.al, 2003). Sasa Djuarsa Sendjaja (1999) berasumsi bahawa media digunakan sebagai alternatif pilihan dalam mencapai pemenuhan keperluan manusia seandainya ia tidak mendapatkannya dalam lingkungan sosialnya. Karena itu wajar, apabila khalayak menjadi sangat selektif dalam memilih produk media.

Menurut Katz (1974) dasar yang lain dari perilaku audien yang aktif berperilaku berdasarkan kebutuhan dan kepuasan merupakan kondisi sosial psikologis seseorang akan menyebabkan adanya keperluan yang menciptakan harapan-harapan terhadap media massa atau sumber-sumber lain, yang membawa kepada perbedaan pola penggunaan media atau keterlibatan dalam aktivitas lainnya yang akhirnya akan menghasilkan pemenuhan keperluan dan konsekuensi lainnya, termasuk yang tidak diharapkan sebelumnya. Karenanya dalam banyak kajian media dan public sphere disebutkan bahwa menilai kebutuhan khalayak sebagaimana disebut di atas adalah juga dengan memperbesar ruang partisipasi masyarakat di media, dengan tujuan agar terbangun rasa sense of belonging terhadap suatu masalah atau kemajuan yang terjadi pada negara.

\section{E. Penutup}

Perlunya memberikan perhatian terhadap kebutuhan masyarakat luas melalui kehadiran media massa hari ini. Hal tersebut tidak berlebihan mengingat penetrasi media demikian besar.

Asumsi bahwa media massa diyakini mampu mengemban tugas sosial masyarakat yang ikut juga mengantarkan bangsa ini menjadi lebih baik juga tidak salah. Cita-cita besar ini dan melekat pada media sebagai industri yang menyerap sumber daya manusia dalam jumlah besar sebanding dengan kerjakerja profesional yang didengungkan di setiap program-program unggulan yang diluncurkan

Demikian juga dengan ketersediaan ruang publik yang dalam hal ini talk show sebagai wajah media massa untuk ruang bicara yang disediakan untuk masyarakat. Kiranya dapat lebih berdaya hari ini, meski masih tertinggal banyak catatan untuk perbaikan ke depan dalam jumlah waktu siaran dan konten yang berimbang.

Hal itu tidak lantas menjadikan media pesimis dan tenggelam dalam 
program-program komersil yang mengatasnamakan masyarakat. Namun yang sebenarnya masih minimnya ketersediaan media massa memberikan ruang bicara dan partisipasi masyarakat menjadi peluru bagi media massa untuk berperan lebih aktif menjemput ekspresi khalayak atau massa yang jumlahnya tidak terbatas ruang dan waktu ini untuk kemudian memberikan poin-poin positif bagi pemerintah, media maupun maasyarakat lewat program perbincangan atau talk show dalam format lain.

\section{F. Daftar Pustaka}

Agus Sudibyo, 2004. Ekonomi Media Penyiaran Agus Sudibyo. Jogjakarta: LkiS

Denis McQuail. 2011. (Terj). Teori Komunikasi Massa. Jakarta: Salemba Humanika

Gun Gun Heryanto. 2006. Media massa dan Public Sphere. DIm Jurnal Dakwah. Vol VIII.No.1 Juni. Jakarta: UIN Syarif Hidayatullah

Harley Prayudha. Radio. Suatu Pengantar untuk Wacana dan Praktik Penyiaran. Bayu Media Publishing Jalaluddin Rakhmat, (1993). Psikologi Komunikasi Edisi Revisi. Bandung: Remaja Rosdakarya.
Juniawati. 2013. Sistem Penyiaran Radio di Indonesia. Pontianak: STAIN Press

John Vivian. 2008. Terj. Teori Komunikasi Massa. Jakarta: Kencana

Morrisan. 2008. Manajemen Media Penyiaran. Strategi Mengelola Radio dan Televisi. Jakarta: Kencana Prenada Media Group

Sasa Djuarsa Sendjaja, et al. (1999). Teori Komunikasi. Jakarta: Pusat Penerbitan Universitas Terbuka.

Saodah Wok, Narimah Ismail, Mohd.Yusof Hussain. (2003). TeoriTeori Komunikasi. Pahang Darul Makmur Malaysia: PTS Publication. www. Kominfo/ Berita kominfo bulan Agustus 2014. Diakses September 2014 www. KPI.go.id. Diakses Oktober 2014 